University of St. Thomas, Minnesota

UST Research Online

2016

\title{
Shared and Shared Alike? Founders' Prior Shared Experience and Performance of Newly Founded Banks
}

\author{
Michael L. DeVaughn \\ University of St. Thomas, Minnesota, Deva2917@stthomas.edu \\ Yangfeng Zheng \\ The University of Hong Kong, yzheng@business.hku.hk
}

Follow this and additional works at: https://ir.stthomas.edu/ocbmgmtpub

Part of the Business Administration, Management, and Operations Commons

This Article is brought to you for free and open access by the Management at UST Research Online. It has been accepted for inclusion in Management Faculty Publications by an authorized administrator of UST Research Online. For more information, please contact asle4660@stthomas.edu. 


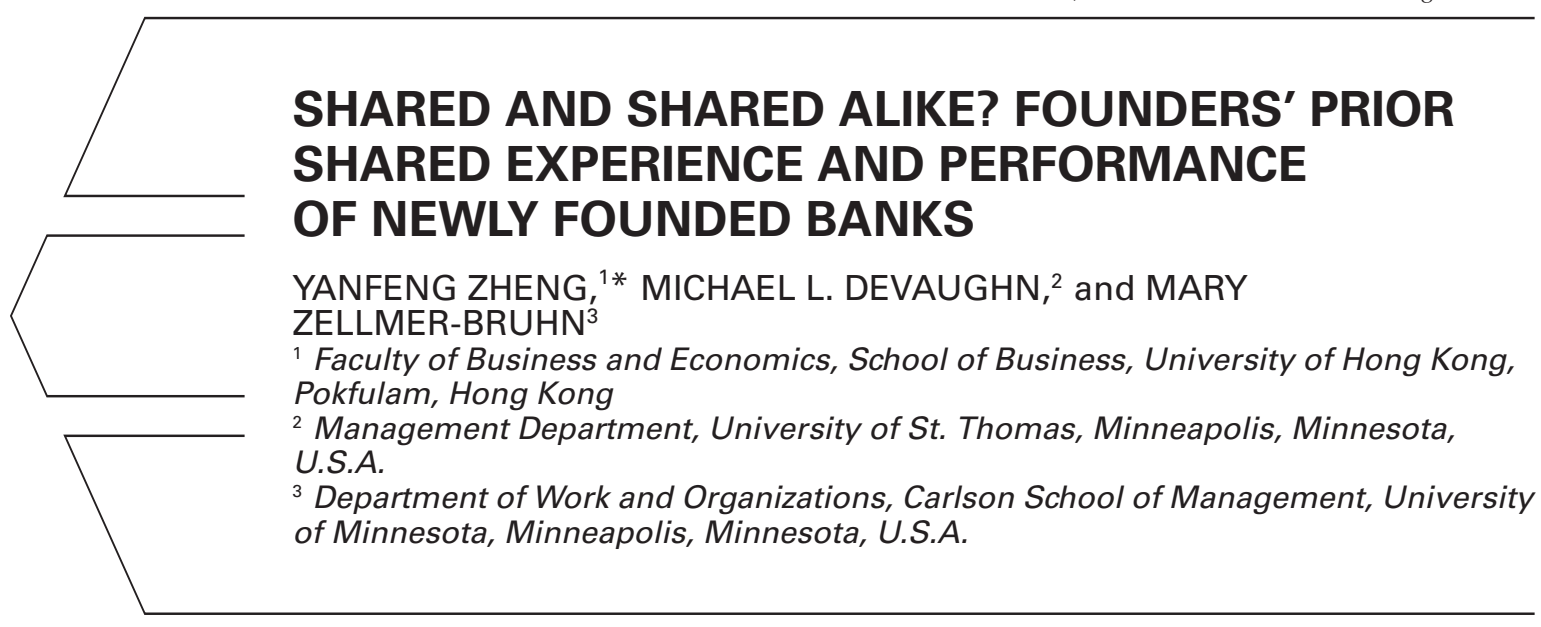

Research summary: Pre-entry industry experience is a central construct in the founding team literature. Research on prior shared experience (PSE) emphasizes that founding teams face challenges integrating and acting on independent experiences, so PSE should be beneficial for new venture performance. Existing studies, however, typically study PSE in blunt terms, expecting that more is better. Instrumental variable analyses of a unique sample of 344 commercial banks founded in four U.S. states between 1996 and 2006 showed that industry-specific PSE may be more or less beneficial, depending on several founding team characteristics. Our findings provide nuance and caution to the narrative that PSE is always beneficial. Under some circumstances, firms with founding team PSE may be no better off than those without founding team PSE, suggesting more research is necessary to understand when and why founding team experience matters to new firms.

Managerial summary: Pre-entry experience of founding teams affects new firm performance, but is hard for founders to leverage separately gained experience. Knowledge moves more readily if sets of managers leave together to start a new firm. But, it may be simplistic to conclude that prior shared experience (PSE) is always good, or better than the sum of independent experiences. In a set of banks founded in four U.S. states between 1996 and 2006, we find that PSE is not necessarily a direct pathway to better bank performance. Characteristics of the PSE, such as the part of industry the former and new banks operate in, can lower its benefit. We also found that the benefits of PSE erode as the entire founding team develops shared history after startup. Our findings have implications for entrepreneurs, investors, and policy-makers. Copyright @ 2015 John Wiley \& Sons, Ltd.

\section{INTRODUCTION}

Founding teams greatly influence new firms' initial strategies, structures, actions, and ultimately, performance (Beckman, 2006; Eisenhardt and

Keywords: founding team; pre-founding experience; new venture performance; new banks; team mental model *Correspondence to: Yanfeng Zheng, 1325 KK Leung Building, University of Hong Kong, Hong Kong. E-mail: yzheng@business.hku.hk
Schoonhoven, 1990; Roure and Keeley, 1990). As such, researchers have become increasingly interested in founding team characteristics to better understand why new firms perform differently (Delmar and Shane, 2006). One characteristic affecting new firm success is knowledge inherited via founding team members' prior industry experience (Agarwal et al., 2004; Bamford, Dean, and McDougall, 2000; Beckman and Burton, 2008; Cooper, Gimeno-Gascon, and Woo, 1994; Klepper 
and Sleeper, 2005). For new ventures that have limited resources, prefounding industry experience is a source of human capital (Helfat and Lieberman, 2002), and is a key criterion stakeholders consider before funding (Delmar and Shane, 2006; Shepherd, 1999).

While some researchers argue that individuals can readily transfer knowledge gained from prior experience to new firms (Burton, Sorensen, and Beckman, 2002; Cooper et al., 1994), others question that possibility (Ganco, 2013; Wezel, Cattani, and Pennings, 2006), perhaps because extant studies typically examine the presence or absence of such experience, or simply look at additive amounts of such experience. The emphasis is on the possession of experience, not the configuration of the experience among team members, and thus, ignores whether experience is relevant and exploitable (Ganco, 2013).

A contrasting approach focuses on whether prior experience is shared. Prior shared experience (PSE) means that some or all of the founding team members worked together before they founded their new venture. Shared experience may be distinct from independent experience in that groups of employees that move together may be better able to transfer knowledge and routines to new firms (Wezel et al., 2006). Joint work history has been associated with more rapid delivery of products to markets (Beckman, 2006) and higher performance (Eisenhardt and Schoonhoven, 1990). This stream of research, though valuable, has implicitly assumed that PSE is always beneficial, the more the better, despite mixed findings or indications of no relationship in some studies (Roure and Keeley, 1990).

More research is needed to develop a better conceptualization of founding team characteristics and to offer insights to stakeholders interested in predicting new venture outcomes. Specifically, research must clarify when PSE improves performance and when it does not by answering several questions. For instance, do the number of team members having shared history, or how long they have shared experience, matter? Do new firms benefit equally from short-duration or long-duration PSE? Likewise, could differences between the context of the prior experience and the new organization affect the utility of the shared experience (Rousseau and Fried, 2001)? Finally, does PSE ever fail to provide advantages over independently acquired experience? To answer these questions, we examine founding team PSE and explore whether PSE characteristics modify performance benefits.

We develop hypotheses regarding PSE qualities and associated benefits (Cannon-Bowers, Salas, and Converse, 1993; Goodman and Shah, 1992; Mohammed, Ferzandi, and Hamilton, 2010; Ren and Argote, 2011). PSE provides founding teams with common routines and an organized understanding of task and team member knowledge that aids team members' information interpretation and interaction with their environment (Klimoski and Mohammed, 1994; Walsh, 1995). Drawing on work in team cognition, we contend that PSE characteristics reflect the similarity and accuracy of knowledge held by founding team members (McIntyre and Foti, 2013), altering the relative benefits of PSE for new firm performance. We focus on prior shared industry-specific experience because it is considered one of the most important resources for founding teams (Delmar and Shane, 2006; Shane and Stuart, 2002).

Our study contributes to the literature on founding team characteristics and new venture performance (Beckman, 2006; Cooper et al., 1994; Eisenhardt and Schoonhoven, 1990) by providing a refined view on how knowledge inheritance from past organizations provides new firms with critical competitive advantages. We identify boundary conditions for PSE benefits, and thus, expand the scope of the observed PSE effects and our ability to predict PSE-related phenomena. Our study also speaks to the entrepreneurial spin-off literature that emphasizes knowledge inherited from prefounding industry experience (Agarwal etal., 2004; Campbell etal., 2012; Klepper and Sleeper, 2005). Specifically, we add to a growing view challenging the general assumption that knowledge inherited from prefounding experience is readily transferred to new firms. Our theory and results are consistent with the view that a team configuration perspective is best for considering inherited knowledge, and that individuals may be constrained in their ability to independently transfer knowledge across organizations (Ganco, 2013).

\section{THEORY AND HYPOTHESES}

Managers become familiar with, and develop knowledge structures about, causal relationships in their task environment through experience (Walsh, 1995). This experience shapes their thinking about 
the core elements of effectiveness in that environment (Mathieu et al., 2000), and thus, provides a cognitive framework for formal analysis, policies, and actions (Benner and Tripsas, 2012; Kiesler and Sproull, 1982). Importantly, experience in one setting affects thinking and behaviors when managers move to a new setting (Phillips, 2005; Simons and Roberts, 2008). Thus, individual founding team members each take to their new firms the experience-based knowledge developed in their previous jobs.

If team members share experience, they are "disposed to store and process stimuli in similar ways" (Klimoski and Mohammed, 1994: 431). Numerous studies show that shared experience generates similar knowledge structures (e.g., Liang, Moreland, and Argote, 1995; Ren and Argote, 2011). Therefore, all teams develop shared organizational knowledge and approaches to problem solving over time, but founding teams with PSE inherit a common basis for collective action because they acquired their experience in the same information environment at their former organization (Walsh, 1995).

Although PSE could pertain to various knowledge contents (Cannon-Bowers etal., 1993), we focus on knowledge from industry-specific experience. New venture research has considered industry-specific experience (Agarwal et al., 2004; Chatterji, 2009; Klepper and Sleeper, 2005; Kor, 2003), but has failed to account for how extensively founding team members developed their industry experience in the same organization. Socialization, adaptation, successes achieved, and lessons learned at a prior organization align individuals' knowledge with the industry task environment where they gained their experience. Industry-specific PSE thereby provides founding teams with common understandings of factors affecting task performance as well as relationships among the factors (Mathieu etal., 2000). Founding team members with PSE hold more similar knowledge structures about the industry-organization environment because they share both organizational history and synchronous industry experience.

\section{PSE and performance}

In start-up organizations, founding teams often constitute the entire organization. As a result, their actions directly determine firm performance (Ucbasaran etal., 2003). When they have PSE, the firm should perform better. Shared experience provides common organizational and industry-related knowledge as well as understanding about each other's relative strengths and weaknesses (Lim and Klein, 2006; Mathieu etal., 2000). The presence of PSE provides an advantage over firms whose founding teams lack PSE because teams have a common organizing framework and routines (Beckman, 2006; Eisenhardt and Schoonhoven, 1990; Phillips, 2002). Shared experience reduces information asymmetry among founders, lowering uncertainty (Becker, 2004). Teams with PSE ought to apply their experience-based knowledge more readily and effectively (Reagans, Argote, and Brooks, 2005).

Prior studies examined PSE and performance, but did not identify conditions that could limit its benefits. Explanations associated with the benefits of PSE - shared knowledge and interaction routines-mirror mechanisms discussed in team mental model research (e.g., Klimoski and Mohammed, 1994), which demonstrates that the similarity and accuracy of shared knowledge and routines gained through experience affect the relative benefit teams accrue (Mohammed etal., 2010). Capitalizing on conceptual correspondence between PSE and team mental models, ${ }^{1}$ we suggest that similarity and accuracy alter the relative benefit of PSE to performance. Similarity reflects whether experiences are alike and overlapping (Edwards et al., 2006); accuracy reflects whether experiences adequately "represent a given knowledge domain" (Edwards et al., 2006: 727). Similarity and accuracy are distinct; knowledge structures and routines can be similar but not accurate, or vice versa (Lim and Klein, 2006).

\section{Similarity}

Founding teams that share similar understandings of the industry task environment should better identify problems and allocate resources to solve them (Edwards et al., 2006), lowering managerial novelty (Shepherd, Douglas, and Shanley, 2000). That is, a founding team must have more than industry-specific experience; the experience must be organized and readily applicable. If founders have PSE, they should be able to act promptly.

\footnotetext{
${ }^{1}$ Team mental models are "organized mental representations of the key elements within a team's relevant environment that are shared across team members (Klimoski and Mohammed, 1994)" (Mohammed et al., 2010: 877).
} 
In contrast, if their experience was obtained independently in separate organizations, founders may disagree about details of the industry environment and force teams to reconcile idiosyncratic individual knowledge during the start-up process.

Unless founding teams are wholesale spin-outs from existing firms, the teams comprise some members with shared experience and others with unique or independent prior experience. At one extreme, if all team members independently gained their prefounding experience at different organizations or at different time points, stark differences could occur among individuals regarding the core elements of success in the industry. At the other extreme, the entire founding team may have worked together in the same context for their entire careers before starting the new firm as may be the case in a university-based spin-out, where founding team members think more alike because they all share similar experience (Rentsch and Klimoski, 2001). Most teams probably fall somewhere between the extremes (Huckman, Staats, and Upton, 2009). PSE therefore varies in "extensiveness," which increases as the proportion of members within the team have longer shared industry-specific experience.

Limited shared experience may be insufficient to understand underlying principles (Gentner, Loewenstein, and Thompson, 2003). Longer and repetitive experience in a task domain may be necessary for similar knowledge structures to develop (Lewis, Lange, and Gillis, 2005). As PSE extensiveness increases, inherited knowledge will be more familiar and overlapping (Goodman and Shah, 1992; Harrison et al., 2003). Extensive PSE increases the similarity of inherited knowledge, shaping expectations and enabling uniform collective action. Similar knowledge is more ready-at-hand to benefit new firm performance. We therefore propose:

\section{Hypothesis 1: New firms with more extensive} PSE will outperform those with less extensive PSE.

The arguments leading to Hypothesis 1 suggest that PSE may bring varying benefits to firm performance because founding teams vary in member shared history prior to founding. However, once the entire team begins working together to lead the new firm, members develop a joint history (Pisano, 1994). Their "shared team-specific experience" (Kor, 2003: 709) reflects accumulated knowledge about one another's "skills, limitations, and idiosyncratic habits" (Kor, 2003: 1084). Shared team-specific experience elevates the shared knowledge the team has about the task as well as about each other in the current task environment (Goodman and Shah, 1992). Thus, team-specific experience represents increasing levels of familiarity in the team, which supports effective collaboration and interaction (Pelled, Eisenhardt, and Xin, 1999). The benefits of PSE will yield to the growing team-specific experience of the entire founding team based on real-time experience acquired while leading the new venture. We therefore expect:

Hypothesis 2: The hypothesized relationship between PSE extensiveness and new firm performance will diminish as a founding team accumulates shared operating experience.

\section{Accuracy}

Experience is most useful when it provides valid knowledge for a new task environment (Leonard-Barton, 1992; Levinthal and March, 1993). Differences between the context where shared experience occurred and where it is applied affect the accuracy of the inherited knowledge and may matter more than the benefits of shared common history (Edwards etal., 2006). If team members apply knowledge and routines regardless of their applicability, performance will suffer (Levitt and March, 1988). Two aspects of shared industry-specific experience might make the associated knowledge more or less congruent with the new firm's task environment: (1) the match or mismatch between the new firm and the within-industry task environment in which the PSE was acquired; and (2) the gap, if any, between the period when PSE was acquired and when the new firm was founded.

Knowledge is setting-specific (Goodman and Shah, 1992); we must consider the context to understand observed phenomena (Rousseau and Fried, 2001). The knowledge and routines developed in one context reflect goals, performance requirements, and problems relevant to that context (Brandon and Hollingshead, 2004). Different industries have different task environments. For example, the commercial airline industry has both legacy and low-cost airlines. Although in the same industry, their business models, strategies, and task demands 
are quite different. If founding members from a legacy airline try to start a low-cost airline, PSE might prove detrimental because knowledge and assumptions may fail to apply to the low-cost airline task environment. When the industry task environment of the new firm is materially different from where PSE was developed, we call it PSE task environment mismatch.

If the new organizational context requirements are similar to the industry task environment where PSE was acquired, PSE should be more beneficial by providing an accurate model for effective action in the new firm (Agarwal et al., 2004). Alternatively, inaccurate shared knowledge causes erroneous judgments, strategic "blind spots" (Edwards et al., 2006; Tripsas and Gavetti, 2000), misguided priorities, and less-effective strategies (Lim and Klein, 2006). Thus, when PSE is highly extensive, but task environments are mismatched, teammates could have very similar but inaccurate ideas about the task environment requirements for the new firm. The benefit of founding members' PSE depends on whether they gained their shared experience in a congruent industry task environment to that of the new organization. PSE benefits are attenuated if the experience leads to inaccurate priorities and strategies. Thus:

Hypothesis 3: The hypothesized relationship between PSE extensiveness and new firm performance will diminish as PSE task environment mismatch increases.

We also expect that a temporal gap between when PSE was obtained and the new firm was founded can affect accuracy. Research typically evaluates inherited knowledge and experience transferred directly and immediately from one context to another (e.g., Ganco, 2013; Lewis et al., 2005), but founders with PSE could have had intervening independent work experiences between the time they shared experience and the time they founded the new firm. As a hypothetical example: Two founding team members worked together at North Star. One left and moved to Solaris; the other left and moved to Luna. Three years later, they reconnected and founded Innovate. Their intervening experiences created a temporal gap between their PSE and the founding of the new firm. Industries are dynamic: Strategies, tactics, customers, and competitors change (Barr, Stimpert, and Huff, 1992). Shared experience in a task environment is fixed in time, which could cause teams to misapply old knowledge and routines to a new, changed environment (Leonard-Barton, 1992; Levitt and March, 1988). Routines, terminology, and narratives become obsolete if not practiced regularly. When temporal gaps occur, the old collective experience may fail to match the demands of the environment at founding. Moreover, the longer people stay in independent environments after having shared experience, the more likely they are individually integrated into different business models and environments. Overall, temporal gaps lower PSE accuracy. As a result, we expect:

Hypothesis 4: The hypothesized relationship between PSE extensiveness and new firm performance will diminish as the PSE temporal gap increases.

\section{METHOD}

\section{Sample}

We tested our hypotheses on a sample of commercial banks chartered in California, Florida, Minnesota, and Texas between 1996 and 2006. We identified the top ten states in terms of new bank founding activity and then selected the four states from that group based on ease of access to data. The four states in our sample accounted for almost half of all new banks established in the United States during our study period. This research setting had several desirable features. Establishing a new bank is an entrepreneurial process through which founders recognize opportunities, mobilize resources, and form new organizations (Shane and Venkataraman, 2000). During the study period, deregulation inspired competitive dynamics (DeYoung, Hunter, and Udell, 2004): a few large banks acquired thousands of small- to medium-sized banks, and many seasoned executives founded new banks in response to emerging opportunities in underserved local markets (Marquis and Lounsbury, 2007). The time period we consider was also advantageous because it was sandwiched between the passage of the Riegle-Neal Interstate Banking and Branch Efficiency Act of 1994, which served to liberalize federal banking rules and increase interest in the banking sector, and the general collapse of the banking sector in 2008. 
The founding team data came primarily from bank charter applications filed with state regulatory agencies such as the Florida Office of Financial Regulation and the Texas Department of Banking. These agencies are responsible for approving new banks and overseeing the operations of all banks chartered in their respective states. This excluded banks filed with national charters that reported to other regulators such as credit unions. We also excluded subsidiaries of established banks and new special purpose banks (e.g., credit card banks) because they generally neither accept consumer and commercial deposits nor make traditional consumer and commercial loans. The exclusions resulted in a final sample of 344 new banks.

Bank charter applications are publicly available via Freedom of Information Act data requests, but we still had to work with regulators to gain access and collect application documents. In some cases, we had to visit an office and copy the documents on the spot. Once we obtained copies of all the charter applications, we hired research assistants, blind to the hypotheses, to read the documents and develop the dataset. An attractive feature of this sample is that, due to tight regulations, the application process required a bank to disclose detailed biographical information on its founders and business plans. As a result, almost all of the data were taken directly from the charter applications without modifications or adjustments. For example, information such as initial capitalization, the distribution of equity shares among founders, and the founders' prior work history are reported on a bank's charter application documents. Falsification of such information can have serious repercussions (e.g., rejected applications and/or confiscated deposits), so this research context has minimal risk of incomplete or inaccurate information.

\section{Dependent variable}

Prior studies on the banking industry have identified several measures of bank performance. Among them, return on assets (ROA) is viewed as a concise and valuable summary statistic of bank performance (Arshadi and Lawrence, 1987). Expressed as net income as a percentage of assets, ROA indicates a bank's ability to earn profit on its assets, and reflects how effectively a bank deploys its assets. We collected ROA information from the Federal Deposit Insurance Corporation (FDIC). Once approved by the regulators, banks may begin operating at any point during a year. Consequently, performance is highly volatile during a new bank's start-up year. Most new banks, however, stabilize their businesses by the end of their second year (the first full calendar year), making comparisons of ROA information across new banks more representative. It is important to also note that most banks sustain negative earnings in their early tenure. This is due to two factors. First, as a new community entrant, a bank must establish a reputation before it can attract loans (a bank's primary earning assets). Second, in a bank's early years, costs are relatively high and limited revenues over which to spread these costs lead to low early profitability. We therefore measured new bank performance as a bank's ROA at the end of its first full calendar year (e.g., if a bank began operations in 1999, we used the ROA of 2000).

\section{Independent variables}

\section{PSE extensiveness}

We measured PSE extensiveness using a relational approach (Berman, Down, and Hill, 2002; Kor, 2003), considering each dyad of founders identified from the bank application documents, and calculating the length of time that each dyad overlapped in their career histories in the same prior banking institution. For example, consider this entry: Founder A "served as President and CEO of Small State Bank from 1994 until its sale to Big National Bank in 1997." Founder B "was CFO and Cashier of Small State Bank from 1994 until its acquisition by Big National Bank in 1997." We captured the duration of each dyad's shared experience as $T_{i j}$. In the example, this value would be four years (Founder A and B overlapped in their prior experience at Small State Bank). We summed all $T_{i j}$ for all dyads to arrive at a total duration of shared experience in the team and then divided the sum of $T_{i j}$ by the total number of dyads in the founding team. Assuming that our sample founding team above has only three members - A, B, and C, we then have three dyads: A-B (four years shared), B-C, and $\mathrm{A}-\mathrm{C}$. The value of the PSE extensiveness variable is therefore 1.33, or four divided by three. This variable provides a measure of the extensiveness of the shared industry-specific experience.

\section{Current shared experience}

As noted, we used ROA for the first full calendar year. As a result, teams in our sample had varying 
amounts of shared current experience before the full year of operation, as reflected by the firm age during the initial operations period prior to the firm performance measure. To address this, we counted the number of months that the team operated during its initial (partial) year as a proxy for its current shared experience. This variable ranged from 1 (i.e., the team began working together in the prior December) to 12 (i.e., the team began working together in the prior January).

\section{PSE task environment mismatch}

In our research setting, a bank's charter indicates its market scope, product portfolio, and competitive strategy. For example, a bank with a national charter typically competes nationwide and focuses on a diversified portfolio of products and services. In contrast, a bank with a state charter competes locally and focuses on in-depth relationships with local businesses (DeYoung et al., 2004). Therefore, while both contexts may be banking, national and state banks have important differences in performance criteria, goals, and problems. Likewise, regulatory differences between the charter types may render knowledge obtained in one context insufficient or erroneous for the other (Whalen, 2002). To capture context match or mismatch between where PSE occurred and the context of the new bank, we examined the charter type of the new bank and of the prior bank(s) where founders developed their PSE. Because a founding team might have more than one independent PSE group, we continued to use a dyadic approach to capture PSE context. Specifically, for each dyad of founders with PSE, if the prior experience occurred in a bank charter type that did not match the new bank's charter type, we coded it as 1 , and 0 if the charter types matched. We then summed the values ( 1 and 0 ) and divided the sum by the total number of PSE dyads in the founding team. The value of this variable ranges from 0 (total match) to 1 (total mismatch). Thus, if the founding team members with PSE all shared their experience in a bank with a different charter type, then this variable would be 1 . If the subset of founding team members with PSE all shared their experience in a bank with the same charter type, then this variable would be 0 . Levels between 0 and 1 occur when more than one subgroup of founding members with prior shared experience were in separate organizations. For instance, consider a founding team with five members with some PSE experience. If two shared their experience in Bank A (charter type matching the new bank) and the other three shared their experience in Bank B (different charter type than the new bank), we have three dyads with mismatched values $(1 \mathrm{~s})$ and one dyad with a matched value (0). The value of PSE Task Environment Mismatch would be $(3+0) /(3+1)=0.75$.

\section{PSE temporal gap}

This variable refers to the gap, if any, between the last year in which members worked together and the year the new bank was established. For each PSE dyad in a founding team, we recorded the last calendar year of shared experience. Across all dyads, we took the average of the last calendar year for the entire PSE cohort. We then took the difference between the last calendar year of shared experience for each dyad and the year the new bank was chartered, summed these differences, and divided by the total number of PSE dyads. Thus, this variable is an overall assessment of the temporal gap (if any) between the shared industry-specific experience and the time of founding the new bank. For example, Bridge Bank, established in 1996, had 11 founders. Seven founders had PSE; five previously worked for Reliable Bank. Some began their tenure in early 1985, but all ended in 1995 because the bank was sold. Two previously worked for Secure Bank from 1989 to 1991. To calculate the temporal gap since PSE occurred in this case, we determined that the five-person PSE group represents 10 separate dyads with the last year of shared experience in 1995 (one-year gap) and that the two-person PSE dyad has a last year of shared experience in 1991 (five-year gap). We averaged these ages to arrive at a gap since PSE of 1.36 years for Bridge Bank.

\section{Control variables}

We included a set of controls based on prior studies on new venture performance in three categories: market conditions, resources, and founding team characteristics.

\section{Founding year}

Because banks in our sample were founded over a decade, we created calendar year dummy variables to account for unobserved market and policy changes, such as labor market variations or regulatory changes. The omitted year is 1996 . 


\section{Founding state}

We also included three dummy variables to account for differences arising from state-level heterogeneities in our sample. The omitted state is Minnesota.

\section{Bank prime loan rate}

Bank prime loan rate is a key macroeconomic factor that can affect bank performance. Bank prime loan rate is based on the Federal Funds rate set by the Federal Reserve Bank. We collected these data from Federal Reserve website.

\section{Unemployment rate}

We included one conventional indicator of economic conditions, unemployment rate, expressed as the percentage of individuals in the current work force who are unemployed. We gathered this information at the metropolitan statistical area (MSA) level from the U.S. Bureau of Economic Analysis.

\section{Local banking density}

A local market characterized by intense competition can have a detrimental effect on a new bank's operations, and substantially hinder profitability (Baum and Mezias, 1992). We included a control measured by the number of similar financial institutions in the same geographic region or MSA. We logged this variable to reduce skewness.

\section{Initial investment capital}

Financial services institutions such as commercial banks are often susceptible to the economies of scale effect (Bamford etal., 2000). We included the natural log of the amount of initial investment capital (in thousands of dollars) with which each new bank opens as a control variable.

\section{Total banking experience}

Banking experience represents knowledge accumulated from years of operations and learning. To calculate this variable, we summed the total number of years of prior banking experience for each founder. As the distribution of this variable is also skewed across new banks, we used its natural log.

\section{Founding team size}

Prior studies have shown that founding team size can be related to the total knowledge stock available to the team (Eisenhardt and Schoonhoven, 1990; Kor, 2003). So we included this control measured by the number of founders.

\section{Founding team diversity}

In addition to bank managers, new bank founders can be local business owners and professionals, such as lawyers. To assess the level of occupational diversity among founders, we constructed Founding Team Diversity using the occupations of the founders filed in the bank's application documents. The Blau index is computed as $1-\Sigma p \mathrm{i}^{2}$, where $p$ is the proportion of founders in a given occupation (excluding bankers) and $i$ is the number of occupations (Harrison and Klein, 2007).

\section{Share distribution}

Founding team members may have uneven levels of motivation and incentives related to their stake in the new venture. Therefore, the distribution of shares among founders may generate different incentives for coordination among and contribution from members (Kotha and George, 2012). We coded share distribution by calculating the standard deviation of each founder's equity percentage.

\section{Analyses}

Our interest was to examine the effects of PSE and its moderating characteristics on firm performance. However, some new banks may have higher performance not because of higher PSE, but because of an unobserved variable influencing both PSE and performance. We then conducted a Hausman test, which yielded a $p$ value of 0.03 , indicating that the estimates of OLS statistically differ from the potentially consistent estimates of 2SLS (Wooldridge, 2002: 118). To address this potential bias, we employed an instrumental variables (IV) approach in our analyses (Bascle, 2008; Wooldridge, 2002). A challenge, however, arises because of the interaction terms for our moderated hypotheses. We reviewed the literature on how to tackle this issue, and found no consensus regarding how to implement an IV approach with interaction terms. From our consideration of the literature, we identified two approaches. 
The first IV approach to handle interaction terms involving an endogenous regressor, which we use to test our hypotheses, was proposed in a recent Management Science article (Samila and Sorenson, 2011: 434). In that study, the authors first regressed the endogenous variable on all excluded IVs and other controls. They then used the predicted values of the endogenous variable to reconstruct interaction terms and bootstrapped the $t$ statistics 10,000 times in the second stage regression since the standard errors no longer follow the $t$ distribution. Following this approach, we regressed PSE on two excluded IVs (described below) and the control variables. We then constructed interaction terms by multiplying the predicted values of PSE and the moderators, and used these terms in the models to test the hypotheses, with bootstrapped standard errors.

The second approach is to instrument all the interaction terms with additional IVs, under the assumption that an interaction term is another endogenous variable. The natural IVs for those interaction terms will be IV(s) $\times$ moderator(s). In our article, this would require eight first-stage IVs because we have two excluded instruments and four independent variables (one main effect and three interaction terms). This approach is not commonly adopted in empirical studies. Nonetheless, we implemented this approach and provide a comparison of the results from the two methods in our results section.

We identified two instruments to employ in our analyses. The first instrument is prior mergers or acquisitions (M\&A), operationalized as the number of founders whose prior banks experienced a merger or acquisition prior to the founding of the new bank. The second instrument is the number of new banks founded in the same geographic region in the previous year, including nonstate chartered banks. The two instruments provide two different mechanisms for PSE. First, significant corporate behaviors such as M\&A often invoke executive turnover. As a result, prior M\&A increases the likelihood that sets of familiar managers leave a particular bank at the same time to look for new opportunities (Deogun, 1996). Second, the number of prior foundings indicates market opportunities for potential bank entrepreneurs (Marquis and Lounsbury, 2007; Wu and Knott, 2006). As a result, a combination of these two variables increases the possibility that a group of familiar bank managers leave to start their own bank. On the other hand, no studies on new bank performance have suggested that these two instruments are correlated with PSE. Indeed, when we regressed ROA on the two instruments, neither showed a significant relationship with performance.

Following convention, we performed additional tests to further assess the quality of the instruments. The first-stage regression of PSE on the two excluded instruments yielded an $F$-statistic of $14.69(p<0.05)$; the coefficients for Prior M\&A and Prior Foundings were both significant at 0.05 level, together suggesting strong instruments (Bascle, 2008; Stock, Wright, and Yogo, 2002). Furthermore, the Hansen J statistic was $1.25(p>0.26)$, indicating exogeneity of the instruments. Last, we also produced OLS estimates (Table 2), as is customary, to provide a basis of comparison.

\section{RESULTS}

Table 1 summarizes the descriptive statistics and correlations. The correlations revealed several notable relationships. For example, PSE extensiveness was positively and significantly related to first year ROA $(r=0.18, p<0.05)$, and current shared experience was also positively and significantly related to performance $(r=0.47, p<0.01)$. Unemployment rate and share distribution among the founding team members were both negatively correlated with performance $(r=-0.14, p<0.05$; $r=-0.15, p<0.05$, respectively).

Table 2 presents the OLS estimates of our hypothesized PSE effects, while Table 3 presents the IV estimates. We will primarily focus on the IV estimates, or Table 3, since it alleviates the endogeneity concern. Hypothesis 1 stated that PSE extensiveness is positively associated with new bank performance. Model 1 of Table 3 reveals a positive and significant relationship between the instrumented PSE extensiveness and new bank performance $(b=0.37$, $p<0.05)$. Hypothesis 1 is therefore supported. This finding has important economic implications: For a new bank with total assets of 100 million dollar, a one standard deviation increase in PSE extensiveness roughly increases the new bank's first year ROA by 37 basis points (or $0.37 \%$ ), a substantial increase given that the mean ROA of our sample banks is just -1.19 percent.

Hypothesis 2 stated that current experience moderates the relationship between PSE extensiveness and firm performance such that as current team-specific experience increases, the positive 


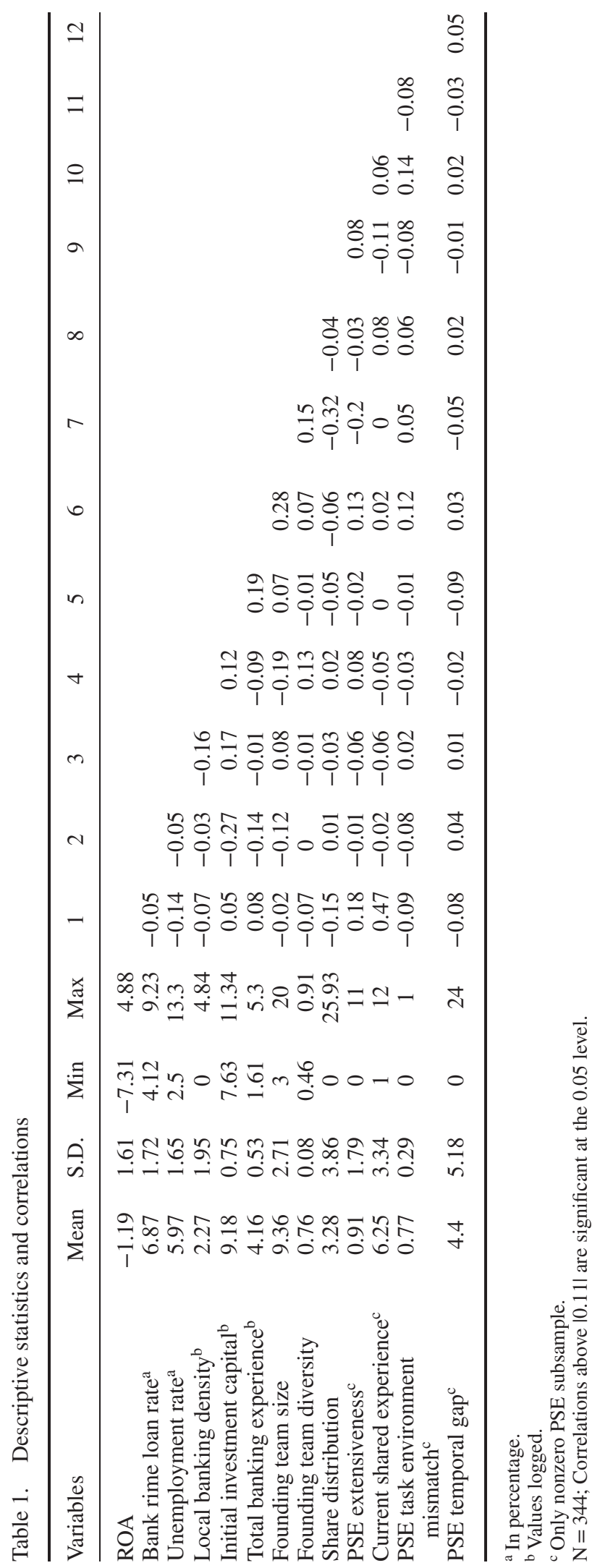


Table 2. OLS estimates of the PSE effects

\begin{tabular}{|c|c|c|c|c|c|}
\hline Variables & $\begin{array}{c}\text { Model } 1 \\
\text { DV: ROA }\end{array}$ & $\begin{array}{l}\text { Model } 2 \text { DV: } \\
\text { ROA }\end{array}$ & $\begin{array}{l}\text { Model } 3 \\
\text { DV: ROA }\end{array}$ & $\begin{array}{l}\text { Model } 4 \\
\text { DV: ROA }\end{array}$ & $\begin{array}{l}\text { Model } 5 \\
\text { DV: ROA }\end{array}$ \\
\hline Year dummies & Included & Included & Included & Included & Included \\
\hline California & $\begin{array}{l}-1.01 * * \\
(-2.97)\end{array}$ & $\begin{array}{l}-0.68 * \\
(-2.25)\end{array}$ & $\begin{array}{l}-1.01 * * \\
(-2.98)\end{array}$ & $\begin{array}{l}-0.94 * * \\
(-2.73)\end{array}$ & $\begin{array}{c}-0.59 * \\
(-1.97)\end{array}$ \\
\hline Florida & $\begin{array}{l}-0.81+ \\
(-1.73)\end{array}$ & $\begin{array}{l}-0.39 \\
(-0.93)\end{array}$ & $\begin{array}{l}-0.83+ \\
(-1.78)\end{array}$ & $\begin{array}{l}-0.71 \\
(-1.52)\end{array}$ & $\begin{array}{l}-0.28 \\
(-0.69)\end{array}$ \\
\hline Texas & $\begin{array}{l}-0.33 \\
(-0.75)\end{array}$ & $\begin{array}{l}-0.14 \\
(-0.37)\end{array}$ & $\begin{array}{l}-0.26 \\
(-0.58)\end{array}$ & $\begin{array}{l}-0.27 \\
(-0.62)\end{array}$ & $\begin{array}{l}-0.00 \\
(-0.00)\end{array}$ \\
\hline Bank prime loan rate & $\begin{array}{l}-0.00 \\
(-0.03)\end{array}$ & $\begin{array}{l}-0.03 \\
(-0.57)\end{array}$ & $\begin{array}{l}-0.01 \\
(-0.17)\end{array}$ & $\begin{array}{l}-0.00 \\
(-0.07)\end{array}$ & $\begin{array}{l}-0.03 \\
(-0.72)\end{array}$ \\
\hline Local banking density & $\begin{array}{l}-0.17^{*} \\
(-2.22)\end{array}$ & $\begin{array}{l}-0.07 \\
(-1.02)\end{array}$ & $\begin{array}{l}-0.19^{*} \\
(-2.45)\end{array}$ & $\begin{array}{l}-0.18^{*} \\
(-2.26)\end{array}$ & $\begin{array}{l}-0.09 \\
(-1.24)\end{array}$ \\
\hline Unemployment rate & $\begin{array}{l}-0.23^{* * *} \\
(-4.42)\end{array}$ & $\begin{array}{l}-0.18 * * * \\
(-3.91)\end{array}$ & $\begin{array}{l}-0.22 * * * \\
(-4.34)\end{array}$ & $\begin{array}{l}-0.22 * * * \\
(-4.43)\end{array}$ & $\begin{array}{l}-0.17 \text { *** } \\
(-3.83)\end{array}$ \\
\hline Initial investment capital & $\begin{array}{c}0.24 \\
(1.62)\end{array}$ & $\begin{array}{c}0.14 \\
(1.09)\end{array}$ & $\begin{array}{c}0.21 \\
(1.45)\end{array}$ & $\begin{array}{c}0.23 \\
(1.59)\end{array}$ & $\begin{array}{c}0.11 \\
(0.86)\end{array}$ \\
\hline Total banking experience & $\begin{array}{c}0.28+ \\
(1.70)\end{array}$ & $\begin{array}{l}0.26+ \\
(1.79)\end{array}$ & $\begin{array}{l}0.29+ \\
(1.80)\end{array}$ & $\begin{array}{l}0.30+ \\
(1.86)\end{array}$ & $\begin{array}{c}0.29 * \\
(1.99)\end{array}$ \\
\hline Founding team size & $\begin{array}{l}-0.03 \\
(-0.79)\end{array}$ & $\begin{array}{l}-0.03 \\
(-0.80)\end{array}$ & $\begin{array}{c}-0.02 \\
(-0.60)\end{array}$ & $\begin{array}{l}-0.04 \\
(-1.02)\end{array}$ & $\begin{array}{l}-0.03 \\
(-0.82)\end{array}$ \\
\hline Founding team diversity & $\begin{array}{l}-0.95 \\
(-0.87)\end{array}$ & $\begin{array}{l}-1.50 \\
(-1.54)\end{array}$ & $\begin{array}{l}-0.87 \\
(-0.80)\end{array}$ & $\begin{array}{l}-0.97 \\
(-0.89)\end{array}$ & $\begin{array}{l}-1.50 \\
(-1.56)\end{array}$ \\
\hline Share distribution & $\begin{array}{l}-0.07 * * \\
(-3.23)\end{array}$ & $\begin{array}{l}-0.05^{* *} \\
(-2.65)\end{array}$ & $\begin{array}{l}-0.07 * * \\
(-3.28)\end{array}$ & $\begin{array}{l}-0.07 * * * \\
(-3.42)\end{array}$ & $\begin{array}{l}-0.05 * * \\
(-2.82)\end{array}$ \\
\hline PSE extensiveness & $\begin{array}{l}0.11 * \\
(2.25)\end{array}$ & $\begin{array}{l}0.11 * \\
(2.43)\end{array}$ & $\begin{array}{l}0.16^{* *} \\
(3.02)\end{array}$ & $\begin{array}{l}0.11 * \\
(2.27)\end{array}$ & $\begin{array}{l}0.16^{* * * *} \\
(3.37)\end{array}$ \\
\hline Current shared experience & & $\begin{array}{l}0.21 * * * \\
(9.59)\end{array}$ & & & $\begin{array}{l}0.21 * * * \\
(9.61)\end{array}$ \\
\hline $\begin{array}{l}\text { PSE extensiveness } \times \text { current } \\
\text { shared experience }\end{array}$ & & $\begin{array}{l}-0.03^{*} \\
(-2.21)\end{array}$ & & & $\begin{array}{l}-0.03 * \\
(-2.33)\end{array}$ \\
\hline $\begin{array}{l}\text { PSE task environment } \\
\text { mismatch }\end{array}$ & & & $\begin{array}{l}-0.81 * \\
(-2.46)\end{array}$ & & $\begin{array}{l}-0.49+ \\
(-1.70)\end{array}$ \\
\hline $\begin{array}{l}\text { PSE extensiveness } \times \text { PSE task } \\
\text { environment mismatch }\end{array}$ & & & $\begin{array}{l}-0.43+ \\
(-1.73)\end{array}$ & & $\begin{array}{l}-0.51 * \\
(-2.33)\end{array}$ \\
\hline PSE temporal gap & & & & $\begin{array}{c}-0.03 \\
(-1.38)\end{array}$ & $\begin{array}{l}-0.02 \\
(-1.55)\end{array}$ \\
\hline $\begin{array}{l}\text { PSE extensiveness } \times \text { PSE } \\
\text { temporal gap }\end{array}$ & & & & $\begin{array}{c}0.02+ \\
(1.81)\end{array}$ & $\begin{array}{l}0.02 * \\
(2.10)\end{array}$ \\
\hline Observations & 344 & 344 & 344 & 344 & 344 \\
\hline$R^{2}$ & 0.24 & 0.43 & 0.26 & 0.25 & 0.45 \\
\hline
\end{tabular}

$* * * p<0.001 ; * * p<0.01 ; * p<0.05 ; \uparrow p<0.10$, two-tailed tests; $z$ scores in parentheses.

relationship between PSE extensiveness and performance declines. The coefficient of the instrumented interaction term was negative and significant when entered alone $(b=-0.06, p<0.01$; Model 2 of Table 3 ) and also when included in the full model with all the interaction terms $(b=-0.05$, $p<0.05$; Model 5 of Table 3), lending support to Hypothesis 2.

Hypothesis 3 proposed that PSE task environment mismatch interacts with PSE extensiveness such that the expected positive relationship between PSE extensiveness and performance will be lower in teams with greater PSE mismatch. The instrumented interaction term is negative and significant both when entered alone $(b=-0.90$, $p<0.10$; Model 3 of Table 3) and when included in the full model containing all the instrumented interaction terms $(b=-0.90, p<0.05$; Model 5 of Table 3). Hypothesis 3 is therefore supported too.

Finally, Hypothesis 4 suggested that as the PSE temporal gap increases, the positive relationship between PSE extensiveness and performance 
Table 3. IV estimates of the PSE effects

\begin{tabular}{|c|c|c|c|c|c|}
\hline Variables & $\begin{array}{c}\text { Model } 1 \\
\text { DV: ROA }\end{array}$ & $\begin{array}{c}\text { Model } 2 \\
\text { DV: ROA }\end{array}$ & $\begin{array}{c}\text { Model } 3 \\
\text { DV: ROA }\end{array}$ & $\begin{array}{c}\text { Model } 4 \\
\text { DV: ROA }\end{array}$ & $\begin{array}{c}\text { Model } 5 \\
\text { DV: ROA }\end{array}$ \\
\hline Year dummies & Included & Included & Included & Included & Included \\
\hline California & $-1.09 * *$ & $-0.73 *$ & $-1.06 * *$ & $-1.06 * *$ & -0.68 \\
\hline Florida & $\begin{array}{l}-0.93+ \\
(-1.87)\end{array}$ & $\begin{array}{l}-0.46 \\
(-1.02)\end{array}$ & $\begin{array}{l}-0.92+ \\
(-1.77)\end{array}$ & $\begin{array}{l}-0.90 * \\
(-1.97)\end{array}$ & $\begin{array}{l}(-1.01) \\
-0.41 \\
(-0.69)\end{array}$ \\
\hline Texas & $\begin{array}{l}-0.26 \\
(-0.55)\end{array}$ & $\begin{array}{c}0.07 \\
(0.14)\end{array}$ & $\begin{array}{l}-0.11 \\
(-0.26)\end{array}$ & $\begin{array}{l}-0.24 \\
(-0.52)\end{array}$ & $\begin{array}{c}0.18 \\
(0.38)\end{array}$ \\
\hline Bank prime loan rate & $\begin{array}{c}2.08 \\
(1.40)\end{array}$ & $\begin{array}{c}2.16 \\
(1.14)\end{array}$ & $\begin{array}{c}1.61 \\
(1.08)\end{array}$ & $\begin{array}{l}2.72+ \\
(1.71)\end{array}$ & $\begin{array}{l}2.01 \\
(1.39)\end{array}$ \\
\hline Local banking density & $\begin{array}{l}-0.19 * \\
(-2.39)\end{array}$ & $\begin{array}{c}-0.09 \\
(-1.13)\end{array}$ & $\begin{array}{l}-0.21 * \\
(-2.43)\end{array}$ & $\begin{array}{l}-0.20 * * \\
(-3.08)\end{array}$ & $\begin{array}{l}-0.11 \\
(-1.38)\end{array}$ \\
\hline Unemployment rate & $\begin{array}{l}-0.19 * * * \\
(-3.59)\end{array}$ & $\begin{array}{l}-0.15^{*} \\
(-2.50)\end{array}$ & $\begin{array}{l}-0.18^{*} \\
(-2.39)\end{array}$ & $\begin{array}{l}-0.18^{* *} \\
(-2.67)\end{array}$ & $\begin{array}{l}-0.14 * \\
(-2.47)\end{array}$ \\
\hline Initial investment capital & $\begin{array}{l}0.64 * * * \\
(3.66)\end{array}$ & $\begin{array}{l}0.51 * * \\
(2.97)\end{array}$ & $\begin{array}{l}0.58 * * * \\
(3.64)\end{array}$ & $\begin{array}{l}0.63 * * * \\
(3.88)\end{array}$ & $\begin{array}{l}0.44 * * \\
(3.19)\end{array}$ \\
\hline Total banking experience & $\begin{array}{c}0.15 \\
(0.80)\end{array}$ & $\begin{array}{l}0.10 \\
(0.53)\end{array}$ & $\begin{array}{c}0.18 \\
(0.92)\end{array}$ & $\begin{array}{c}0.22 \\
(1.26)\end{array}$ & $\begin{array}{l}0.18 \\
(0.96)\end{array}$ \\
\hline Founding team size & $\begin{array}{c}0.01 \\
(0.31)\end{array}$ & $\begin{array}{c}0.02 \\
(0.33)\end{array}$ & $\begin{array}{c}0.02 \\
(0.36)\end{array}$ & $\begin{array}{l}-0.01 \\
(-0.11)\end{array}$ & $\begin{array}{c}0.01 \\
(0.25)\end{array}$ \\
\hline Founding team diversity & $\begin{array}{c}-0.78 \\
(-0.70)\end{array}$ & $\begin{array}{l}-1.01 \\
(-0.77)\end{array}$ & $\begin{array}{c}-0.77 \\
(-0.79)\end{array}$ & $\begin{array}{c}-0.89 \\
(-0.82)\end{array}$ & $\begin{array}{l}-1.23 \\
(-1.20)\end{array}$ \\
\hline Share distribution & $\begin{array}{l}-0.07 * * \\
(-3.24)\end{array}$ & $\begin{array}{l}-0.06^{*} \\
(-2.47)\end{array}$ & $\begin{array}{l}-0.07 * * \\
(-2.75)\end{array}$ & $\begin{array}{l}-0.07 * \\
(-2.48)\end{array}$ & $\begin{array}{l}-0.06^{*} \\
(-2.36)\end{array}$ \\
\hline PSE extensiveness ${ }^{\mathrm{a}}$ & $\begin{array}{c}0.37 * \\
(2.32)\end{array}$ & $\begin{array}{l}0.42 * \\
(2.26)\end{array}$ & $\begin{array}{c}0.42 * \\
(2.37)\end{array}$ & $\begin{array}{c}0.31 * \\
(1.98)\end{array}$ & $\begin{array}{c}0.40 * \\
(2.19)\end{array}$ \\
\hline Current shared experience & & $\begin{array}{l}0.20 * * * \\
(9.58)\end{array}$ & & & $\begin{array}{l}0.20 * * * \\
(8.17)\end{array}$ \\
\hline PSE extensiveness $\times$ current shared experience & & $\begin{array}{l}-0.06 * * \\
(-2.63)\end{array}$ & & & $\begin{array}{l}-0.05^{*} \\
(-2.42)\end{array}$ \\
\hline PSE task environment mismatch & & & $\begin{array}{l}-1.06 * * \\
(-3.03)\end{array}$ & & $\begin{array}{l}-0.69 * \\
(-2.26)\end{array}$ \\
\hline PSE extensiveness $\times$ PSE task environment mismatch & & & $\begin{array}{l}-0.90+ \\
(-1.91)\end{array}$ & & $\begin{array}{l}-0.90 * \\
(-2.03)\end{array}$ \\
\hline PSE temporal gap & & & & $\begin{array}{c}-0.02 \\
(-1.09)\end{array}$ & $\begin{array}{l}-0.02 \\
(-1.42)\end{array}$ \\
\hline PSE extensiveness $\times$ PSE temporal gap & & & & $\begin{array}{c}-0.02 \\
(1.57)\end{array}$ & $\begin{array}{c}-0.02 \\
(1.10)\end{array}$ \\
\hline Observations & 344 & 344 & 344 & 344 & 344 \\
\hline$R^{2}$ & 0.17 & 0.33 & 0.19 & 0.21 & 0.40 \\
\hline
\end{tabular}

${ }^{a}$ Instrumented.

${ }^{* * *} p<0.001 ; * * p<0.01 ; * p<0.05 ; \dagger p<0.10$, two-tailed tests; bootstrapped $z$-scores in parentheses.

declines. The estimate for the instrumented interaction term between temporal gap and extensiveness was negative, but not significant both when entered alone $(b=-0.02, p>0.10$; Model 4 of Table 3) and in the full model $(b=-0.02, p>0.10$; Model 5 of Table 3). Although the OLS estimates show a significant interaction between PSE and the temporal gap $(b=-0.02, p<-0.05$; Model 5 of Table 2), the IV estimates seem to suggest that such effect is less significant, thus providing only mixed support for Hypothesis 4.

\section{Split sample tests}

We conducted a series of subsample comparison tests by dividing the sample into four quadrants and creating four dummy variables indicating the four possible combinations for each interaction term (i.e., high PSE/high moderator, high PSE/low moderator, low PSE/high moderator, and low PSE/low moderator). To be compatible with our IV approach, we used the predicted values of PSE to split the sample. We treated the zero-PSE subsample as the 
Table 4. Split sample analyses ${ }^{\mathrm{a}}$

\begin{tabular}{|c|c|c|c|}
\hline Variables & $\begin{array}{l}\text { Model } 1 \\
\text { DV: ROA }\end{array}$ & $\begin{array}{l}\text { Model } 2 \\
\text { DV: ROA }\end{array}$ & $\begin{array}{l}\text { Model } 3 \\
\text { DV: ROA }\end{array}$ \\
\hline \multirow{3}{*}{$\begin{array}{l}\text { All controls } \\
\text { Low PSE/low current } \\
\text { shared experience }\end{array}$} & Included & \multirow[t]{9}{*}{ Included } & \multirow[t]{17}{*}{ Included } \\
\hline & -0.26 & & \\
\hline & $(-1.12)$ & & \\
\hline \multirow{2}{*}{$\begin{array}{l}\text { Low PSE/high current } \\
\text { shared experience }\end{array}$} & $0.98 * * *$ & & \\
\hline & $(4.02)$ & & \\
\hline \multirow{2}{*}{$\begin{array}{l}\text { High PSE/low current } \\
\text { shared experience }\end{array}$} & -0.16 & & \\
\hline & $(-0.69)$ & & \\
\hline \multirow{2}{*}{$\begin{array}{l}\text { High PSE/high current } \\
\text { shared experience }\end{array}$} & $1.22 * * *$ & & \\
\hline & $(5.26)$ & & \\
\hline \multirow{2}{*}{$\begin{array}{l}\text { Low PSE/low } \\
\text { mismatch }\end{array}$} & \multicolumn{2}{|r|}{0.26} & \\
\hline & \multicolumn{2}{|r|}{$(0.97)$} & \\
\hline \multirow{2}{*}{$\begin{array}{l}\text { Low PSE/high } \\
\text { mismatch }\end{array}$} & \multicolumn{2}{|r|}{0.33} & \\
\hline & \multirow{2}{*}{\multicolumn{2}{|c|}{$\begin{array}{l}(1.28) \\
068 *\end{array}$}} & \\
\hline High PSE/low & \multirow{2}{*}{\multicolumn{2}{|c|}{$0.68 *$}} & \\
\hline \multirow{2}{*}{$\begin{array}{c}\text { mismatch } \\
\text { High PSE/high }\end{array}$} & & & \\
\hline & \multicolumn{2}{|r|}{ (2.53) } & \\
\hline $\begin{array}{l}\text { High PSE/high } \\
\text { mismatch }\end{array}$ & \multicolumn{2}{|r|}{ (1.68) } & \\
\hline \multirow{2}{*}{$\begin{array}{l}\text { Low PSE/low } \\
\text { temporal gap }\end{array}$} & & & 0.27 \\
\hline & & & $(0.95)$ \\
\hline \multirow{2}{*}{$\begin{array}{l}\text { Low PSE/high } \\
\text { temporal gap }\end{array}$} & & & 0.32 \\
\hline & & & (1.32) \\
\hline \multirow{2}{*}{$\begin{array}{l}\text { High PSE/low } \\
\text { temporal gap }\end{array}$} & & & $0.48 \dagger$ \\
\hline & & & (1.90) \\
\hline \multirow{2}{*}{$\begin{array}{l}\text { High PSE/high } \\
\text { temporal gap }\end{array}$} & & & $0.51 *$ \\
\hline & & & $(2.11)$ \\
\hline Observations & 344 & 344 & 344 \\
\hline$R^{2}$ & 0.34 & 0.23 & 0.23 \\
\hline
\end{tabular}

${ }^{a}$ Use predicted values of PSE to split the sample.

$* * * p<0.001 ; * * p<0.01 ; * p<0.05 ; \dagger p<0.10$, two-tailed tests; $z$ scores in parentheses.

baseline or the omitted group. So the coefficients for the four subsample dummies will indicate whether a specific PSE quadrant performs better (or worse) than the zero-PSE subsample. These split sample analyses allowed us to more accurately evaluate the boundary conditions of the PSE effect. ${ }^{2}$ Table 4 shows results revealing additional insights into the relative benefits of PSE.

First, we considered current shared experience. In this analysis, two subgroups showed superior performance to banks with no PSE: (1) high PSE and high current shared experience $(b=1.22$, $p<0.001)$, and (2) low PSE and high current shared experience $(b=0.98, p<0.001)$. These findings suggest that while current team shared experience

\footnotetext{
${ }^{2}$ We thank an anonymous reviewer for this valuable suggestion.

overshadows PSE, it is more valuable to teams with at least some PSE than to teams with no PSE.

Next, we considered task environment mismatch. Here, only the subgroup of banks with high PSE/low mismatch performed better than banks without PSE $(b=0.68, p<0.05)$. An important insight from this is that when banks have high but mismatched PSE, they perform no better than banks without PSE. While we found no case where banks with PSE performed worse than teams without PSE, these results suggest that PSE benefits may occur only when the PSE was developed in a task environment similar to the environment of the new organization.

Finally, we considered the moderating effect of PSE temporal gap. Here, we found that both the High PSE/Low Temporal Gap and High PSE/High Temporal Gap combinations perform better than the zero-PSE subsample $(b=0.48, p<0.10 ; b=0.51$, $p<0.05)$. These results suggest that banks with high PSE, regardless of a temporal gap, outperform banks without PSE, and that a temporal gap is more problematic for teams with lower PSE.

\section{Robustness tests}

We conducted several tests to further assess the robustness of our key findings. First, we tested alternative specifications of our dependent variable. For instance, we used the average of three calendar years' ROA as an alternative to the first full calendar year. As our theory suggests, the more new ventures develop their own experience, the less the impact of founding conditions such as PSE. Consistent with this prediction, the PSE effect, as well as its boundary conditions, largely holds, with some loss of statistical significance. For example, PSE still exerts a positive and significant impact $(b=0.23, p<0.05)$ on the new dependent variable. We also replaced local banking density with the Herfindahl-Hirschman index (HHI), operationalized as the distribution of deposits across banks in the same region. The HHI influences bank performance, particularly in highly concentrated regions (Dick, 2007). Our results were robust to this alternative control. To evaluate whether our results were sensitive to extreme cases, we excluded outliers in key variables (e.g., founding team size, PSE extensiveness, and PSE temporal gap). We found similar results after these exclusions.

Finally, in the analyses section we described an alternative instrumental variable approach for 
cases with interaction terms constructed involving an endogenous regressor. For comparison, we implemented this approach with ivreg2 command in STATA 13. The estimates produced by this approach are slightly weaker, but compatible with those presented in the results section. However, we found evidence of weak instruments in the first stage (i.e., the CD Wald $F$ statistic is lower than the Stock Yogo 10\% critical value) (Stock et al., 2002), so we re-estimated the parameters with limited information maximum likelihood (LIML), which is robust to weak instruments, and therefore, produces more trustworthy estimates (Baum, Schaffer, and Stillman, 2007: 478). This was done using the LIML option of ivreg2 in STATA (Bascle, 2008: 298-301). The LIML models produced similar estimates to the 2SLS results. Complete results for the instrumented interaction terms approach using 2SLS and LIML, along with the first-stage regression results for both models are available in Tables $\mathrm{S} 1-\mathrm{S} 3$.

For comparison, we present the coefficients and significance levels for our hypotheses tests across the estimation approaches in Table 5. By cross-checking estimates generated by different specifications, our key findings hold. For example, regardless of the IV approach, the main PSE effect is positive and significant in most models. This effect is inflated in instrumented estimations as compared to in OLS estimations, largely because of the inflated standard errors (Wooldridge, 2002). Finally, the approach in our results section makes sense because our interaction terms are not nonlinear functions of the endogenous variables (Wooldridge, 2002: 236), but rather products of the endogenous variable and moderators. Since these moderators are used in the first stage regression to project PSE, the linear projection of interaction terms would be the same as the interaction of fitted value of PSE and moderators. Statistically, this can be shown by the property of conditional expectation that $\mathrm{E}(\mathrm{y} \times \mathrm{zlz})=\mathrm{E}(\mathrm{ylz}) \times \mathrm{z}$. The interaction terms therefore do not introduce endogeneity beyond what's embedded in PSE.

\section{DISCUSSION AND CONCLUSION}

Entrepreneurs' prefounding industry experience is central to founding team research and entrepreneurial practices. Extant studies on founding teams, however, often assume that individuals can readily transfer their prior industry experience to new firms, even if founders gained their experience independently. Nevertheless, recent research suggests that individual knowledge inherited from prefounding experience may be difficult to integrate and transform into competitive advantages. Drawing on team mental model theory, we propose that PSE characteristics are related to similarity and accuracy in founding team members' inherited knowledge. We empirically examine the PSE benefit and its boundary conditions in a setting of newly founded banks in four states of the United States. Our results contribute to and extend theory about founding teams and new firm performance, and offer new avenues for future research.

\section{Theoretical implications}

Our study extends research on the impact of founding team characteristics on new venture performance (Beckman, 2006; Eisenhardt and Schoonhoven, 1990; Roure and Keeley, 1990). Drawing on a distinction made in the team mental model literature, we identified two dimensions of PSE that should be considered to assess its potential benefit: similarity and accuracy (Mohammed et al., 2010). Considering similarity highlights aspects of PSE that explain its benefit. Specifically, the finding that PSE extensiveness is positively associated with firm performance challenges existing studies that examine founder prior experience nominally or additively, and suggests that those studies may be capturing only a part of the prefounding experience story. Future research should account for distinctions between independent and shared experience in evaluating the impact of experience on new firm performance.

Our findings also enrich the entrepreneurial learning literature. Given the challenges new firms face in their early existence, PSE is an important founding team characteristic for researchers to include in studies examining initial performance differences in new firms. Yet, our finding for the moderating effect of current shared experience shows that the PSE effect can quickly give way to current shared experience such that the benefits of PSE are likely seen early on (Harrison et al., 2003). This suggests that it is important for future research to explore the duration of the benefits of inherited knowledge or congenital learning. Even so, Beckman and her colleague (Beckman 
Shared and Shared Alike?

Table 5. Comparing coefficients across estimation approaches

\begin{tabular}{|c|c|c|c|c|}
\hline Key predictors & OLS & $\begin{array}{c}\text { Instrumented } \\
\text { PSE with two IVs }\end{array}$ & Two SLS with eight IVs & LIML with eight IVs \\
\hline PSE & $0.16^{* *}$ & $0.40 *$ & $0.38+(p=0.053)$ & $0.41+(p=0.06)$ \\
\hline PSE $\times$ current & $-0.03 *$ & $-0.05^{*}$ & $-0.05^{*}$ & $-0.06 *$ \\
\hline $\mathrm{PSE} \times$ mismatch & $-0.51 *$ & $-0.90 *$ & $-0.95 *$ & $-0.97 *$ \\
\hline PSE $\times$ Temporal gap & $-0.02 *$ & -0.02, n.s. & 0.00, n.s. & 0.00, n.s. \\
\hline
\end{tabular}

${ }^{* *} p<0.01 ; * p<0.05 ; \dagger p<0.10$; n.s. $p>0.1$; two-tailed tests; $z$ scores in parentheses.

and Burton, 2008) concluded that the background of founders demonstrates a path-dependent effect on the evolution of founding team composition, which is consistent with our split sample finding that teams with any PSE continue to outperform teams without PSE as current shared experience increases. As such, founders' common prior affiliation may exert intriguing effects on new venture performance.

Finally, our study contributes complementary insights to the entrepreneurial spin-off literature. The core argument in this literature is that founders of new firms often inherit valuable industry knowledge from their past working experience, and therefore, gain competitive advantages over startups without such experience (Agarwal etal., 2004; Klepper and Sleeper, 2005). Some studies have shown that those spin-offs not only perform better than de novo startups, but in some industries, even hurt the performance of their past employers (Campbell et al., 2012). That said, how exactly the founders inherit or exploit knowledge from their prefounding industry experience is not well theorized. As a result, we are left with a simplistic account, which suggests that the more prefounding industry experience, the better. Our results that PSE task environment mismatch reduces the PSE effect suggest that under some circumstances a founding team may inherit inappropriate knowledge. The split sample results showed that, in some cases, accuracy-reducing PSE characteristics, such as mismatched task environment or temporal gap, render teams with PSE no better off than those without. These results show that we are far from concluding that more PSE is better, or that PSE is always better than unshared experience. While we did not observe that low accuracy damaged firm performance, or made teams with PSE worse than teams without, future research should consider other industry settings and other characteristics of shared inherited knowledge to explore this possibility.

\section{Practical implications}

Broadly speaking, external stakeholders of new ventures, such as venture capitalists, must pay careful attention to founding team characteristics. Founding teams are widely believed to bring diverse skills and knowledge that benefit new firms (Cooper etal., 1994; Delmar and Shane, 2006). Yet, qualities of their prefounding experience may determine whether they can utilize the stock of skills and knowledge. If the knowledge gained from the shared experience is compatible with the novel task environment, PSE could be the integrating force that releases the potential. In contrast, erroneous routines could render PSE less beneficial or even harmful.

With respect to banking, regulators have long considered PSE among founders of new banks to be of unequivocal benefit. Bank policies governing new bank formation reflect this belief. For example, the Office of the Comptroller of the Currency (OCC), the primary federal regulator that oversees national banks, provided a streamlined application process for new bank founding teams when a majority of their members exhibited prior banking experience and cohesiveness. The agency considered a founding team to be "cohesive" if most of its members had been associated with one another for three or more years as directors or officers at the same satisfactorily performing, federally insured financial institution (Comptroller's Corporate Manual). Our results suggest that this regulatory policy should strongly consider the type of institution where the banking experience was acquired.

Beyond PSE, our results reveal interesting insights into contributors to new bank performance. For instance, the team's aggregate banking experience is important, but becomes less significant when PSE extensiveness is considered: Beyond industry-specific experience, the team must be able to act on the experience. Furthermore, prior 
founding experience did little to boost new bank performance. Share distribution among founders was consistently and negatively related to new bank performance across model specifications. Future investigations can use these findings to further inform policy and managerial practices in the banking industry.

\section{Limitations and future directions}

Of course, our study has limitations. First, despite the benefits of the archival data and our research design, the theoretical mechanisms through which PSE influences new firm performance require further investigation. Future research should formally assess how extensively the configuration and context of PSE influences the similarity and accuracy of inherited knowledge as hypothesized. Another limitation is that we conducted our empirical tests within a single industry. Although our research setting has advantages, such as accurate and complete information on founding teams, the uniqueness of the banking industry is noteworthy. For example, heavy regulations may significantly hamper entries and protect the new banks from failures. Future research should examine whether the relationships we observed hold in other industries or across industries.

\section{CONCLUSION}

Our study supports the view that industry-specific experience of founding team members influences new venture performance, particularly when founding team members shared that experience. Importantly, however, our findings provide nuance and caution to the narrative that prior shared experience is always beneficial. Shared industry-specific experience may be more or less beneficial, depending on its characteristics. Under some circumstances, as our subgroup analyses revealed, founding team PSE offers no more benefits for new firms than no founding team PSE: Shared industry-specific experience is valuable but with limitations.

\section{ACKNOWLEDGEMENTS}

We thank editor Alfonso Gambardella, two anonymous reviewers, Christine Beckman, Martin Ganco, Yan Gong, Jing Liu, Myles Shaver, Aaron
Sojourner, and Akbar Zaheer for their helpful comments and feedback. We also appreciate assistance from Endy Chow, Doug Giddings, Arjyo Mitra, and Judy Zhu for data collection and coding. This research was supported in part by the Research Grants Council of the Hong Kong Special Administrative Region (Project code: HKU 793513B). All errors are ours.

\section{REFERENCES}

Agarwal R, Echambadi R, Franco AM, Sarkar M. 2004. Knowledge transfer through inheritance: spinout generation, development, and survival. Academy of Management Journal 47(4): 501-522.

Arshadi N, Lawrence EC. 1987. An empirical investigation of new bank performance. Journal of Banking and Finance 11(1): 33-48.

Bamford CE, Dean TJ, McDougall PP. 2000. An examination of the impact of initial founding conditions and decisions upon the performance of new bank start-ups. Journal of Business Venturing 15(3): 253-277.

Barr PS, Stimpert JL, Huff AS. 1992. Cognitive change, strategic action, and organizational renewal. Strategic Management Journal 13(5): 15-26.

Bascle G. 2008. Controlling for endogeneity with instrumental variables in strategic management research. Strategic Organization 6(3): 285-327.

Baum CF, Schaffer ME, Stillman S. 2007. Enhanced routines for instrumental variables/generalized method of moments estimation and testing. Stata Journal. 7(4):465-506.

Baum JAC, Mezias SJ. 1992. Localized competition and organizational failure in the manhattan hotel industry, 1898-1990. Administrative Science Quarterly 37(4): 580-604.

Becker MC. 2004. Organizational routines: a review of the literature. Industrial and Corporate Change 13(4): 643-677.

Beckman CM. 2006. The influence of founding team company affiliations on firm behavior. Academy of Management Journal 49(4): 741-758.

Beckman CM, Burton DM. 2008. Founding the future: path dependence in the evolution of top management teams from founding to ipo. Organization Science 19(1): 3-24.

Benner MJ, Tripsas M. 2012. The influence of prior industry affiliation on framing in nascent industries: the evolution of digital cameras. Strategic Management Journal 33(3): 277-302.

Berman SL, Down J, Hill CWL. 2002. Tacit knowledge as a source of competitive advantage in the national basketball association. Academy of Management Journal 45(1): 13-31.

Brandon DP, Hollingshead AB. 2004. Transactive memory systems in organizations: matching tasks, expertise, and people. Organization Science 15(6): 633-644.

Burton DM, Sorensen JB, Beckman CM. 2002. Coming from good stock: career histories and new venture formation. In Research in the Sociology of Organizations, 
Lounsbury M, Ventresca MJ (eds). Elsevier (JAI Press): Oxford, UK; 229-262.

Campbell B, Ganco M, Franco A, Agarwal R. 2012. Who leaves, where to, and why worry? Employee mobility, entrepreneurship and effects on source firm performance. Strategic Management Journal 33(1): 65-87.

Cannon-Bowers JA, Salas E, Converse S. 1993. Shared mental models in expert team decision making. In Current Issues in Individual and Group Decision Making, Castellan NJ Jr (ed). Erlbaum: Hillsdale, NJ; 221-246.

Chatterji AK. 2009. Spawned with a silver spoon? Entrepreneurial performance and innovation in the medical device industry. Strategic Management Journal 30(2): 185.

Cooper AC, Gimeno-Gascon JF, Woo CY. 1994. Initial human and financial capital as predictors of new venture performance. Journal of Business Venturing 9(5): $371-395$.

Delmar F, Shane S. 2006. Does experience matter? The effect of founding team experience on the survival and sales of newly founded ventures. Strategic Organization 4(3): 215-247.

Deogun N. 4 March 1996. Back to the Fray: Displaced by Mergers, Some Bankers Launch Their Own Start-Ups - They Win Over Customers With Personal Service Popular in Small Towns-A Barbell-Shaped Industry Wall Street Journal, New York. page A1.

DeYoung R, Hunter WC, Udell GF. 2004. The past, present, and probable future for community banks. Journal of Financial Services Research 25(2-3): $85-133$.

Dick AA. 2007. Market size, service quality, and competition in banking. Journal of Money, Credit and Banking 39(1): 49-81.

Edwards BD, Day EA, Arthur W, Bell ST. 2006. Relationships among team ability composition, team mental models, and team performance. Journal of Applied Psychology 91(3): 727-736.

Eisenhardt KM, Schoonhoven CB. 1990. Organizational growth: linking founding team, strategy, environment, and growth among U.S. semiconductor ventures, 1978-1988. Administrative Science Quarterly 35(3): $504-529$.

Ganco M. 2013. Cutting the gordian knot: the effect of knowledge complexity on employee mobility and entrepreneurship. Strategic Management Journal 34(6): 666-686.

Gentner D, Loewenstein J, Thompson L. 2003. Learning and transfer: a general role for analogical encoding. Journal of Education and Psychology 95(2): 393-408.

Goodman PS, Shah S. 1992. Familiarity and work group outcomes. In Group Processes and Productivity, Worchel S, Wood W, Simpson JA (eds). Sage Publications: Newbury Park, CA; 578-586.

Harrison DA, Klein KJ. 2007. What's the difference? Diversity constructs as separation, variety, or disparity in organizations. Academy of Management Review 32(4): 1199-1228.

Harrison DA, Mohammed S, McGrath JE, Florey AT, Vanderstoep SW. 2003. Time matters in team performance: effects of member familiarity, entrainment, and task discontinuity on speed and quality. Personnel Psychology 56(3): 633-669.

Helfat CE, Lieberman MB. 2002. The birth of capabilities: market entry and the importance of pre-history. Industrial and Corporate Change 11(4): 725-760.

Huckman RS, Staats BR, Upton DM. 2009. Team familiarity, role experience, and performance: evidence from indian software services. Management Science 55(1): 85-100.

Kiesler S, Sproull L. 1982. Managerial response to changing environments: perspectives on problem sensing from social cognition. Administrative Science Quarterly 27(4): 548-570.

Klepper S, Sleeper S. 2005. Entry by spinoffs. Management Science 51(8): 1291-1306.

Klimoski R, Mohammed S. 1994. Team mental model: construct or metaphor? Journal of Management 20(2): 403-437.

Kor YY. 2003. Experience-based top management team competence and sustained growth. Organization Science 14(6): 707-719.

Kotha R, George G. 2012. Friends, family, or fools: entrepreneur experience and its implications for equity distribution and resource mobilization. Journal of Business Venturing 27(5): 525-543.

Leonard-Barton D. 1992. Core capabilities and core rigidities: a paradox in managing new product development. Strategic Management Journal 13(S1): 111-125.

Levinthal DA, March JG. 1993. The myopia of learning. Strategic Management Journal 14(S2): 95-112.

Levitt B, March JG. 1988. Organizational learning. Annual Review of Sociology 14: 319-340.

Lewis K, Lange D, Gillis L. 2005. Transactive memory systems, learning, and learning transfer. Organization Science 16(6): 581-598.

Liang WD, Moreland R, Argote L. 1995. Group versus individual training and group performance: the mediating factor of transactive memory. Personality and Social Psychology Bulletin 21(4): 384-393.

Lim B-C, Klein KJ. 2006. Team mental models and team performance: a field study of the effects of team mental model similarity and accuracy. Journal of Organizational Behavior 27(4): 403-418.

Marquis C, Lounsbury M. 2007. Vive la resistance: competing logics and the consolidation of U.S. Community banking. Academy of Management Journal 50(4): 799-820.

Mathieu JE, Goodwin GF, Heffner TS, Salas E, Cannon-Bowers JA. 2000. The influence of shared mental models on team process and performance. Journal of Applied Psychology 85(2): 273-283.

McIntyre HH, Foti RJ. 2013. The impact of shared leadership on teamwork mental models and performance in self-directed teams. Group Processes and Intergroup Relations 16(1): 46-57.

Mohammed S, Ferzandi L, Hamilton K. 2010. Metaphor no more: a 15-year review of the team mental model construct. Journal of Management 36(4): 876-910.

Pelled LH, Eisenhardt KM, Xin KR. 1999. Exploring the black box: an analysis of work group diversity, conflict, and performance. Administrative Science Quarterly 44(1): $1-28$. 
Phillips DJ. 2002. A genealogical approach to organizational life chances: the parent-progeny transfer among silicon valley law firms, 1946-1996. Administrative Science Quarterly 47(3): 474-506.

Phillips DJ. 2005. Organizational geneologies and the persistence of gender inequality: the case of silicon valley law firms. Administrative Science Quarterly 50(2): 440-472.

Pisano GP. 1994. Knowledge, integration, and the locus of learning: an empirical analysis of process development. Strategic Management Journal 15(S1): 85-100.

Reagans R, Argote L, Brooks D. 2005. Individual experience and experience working together: predicting learning rates from knowing who knows what and knowing how to work together. Management Science 51(6): 869-881.

Ren Y, Argote L. 2011. Transactive memory systems 1985-2010: an integrative framework of key dimensions, antecedents, and consequences. Academy of Management Annals 5(1): 189-229.

Rentsch JR, Klimoski RJ. 2001. Why do "great minds" think alike? Antecedents of team member schema agreement. Journal of Organizational Behavior 22(2): 107-120.

Roure JB, Keeley RH. 1990. Predictors of success in new technology based ventures. Journal of Business Venturing 5(4): 201.

Rousseau DM, Fried Y. 2001. Location, location, location: contextualizing organizational research. Journal of Organizational Behavior 22(1): 1-13.

Samila S, Sorenson O. 2011. Noncompete covenants: incentives to innovate or impediments to growth. Management Science 57(3): 425-438.

Shane S, Stuart T. 2002. Organizational endowments and the performance of university start-ups. Management Science 48(1): 154-170.

Shane S, Venkataraman S. 2000. The promise of entrepreneurship as a field of research. Academy of Management Review 25(1): 217-226.

Shepherd DA. 1999. Venture capitalists' assessment of new venture survival. Management Science 45(5): $621-632$.

Shepherd DA, Douglas EJ, Shanley M. 2000. New venture survival: ignorance, external shocks, and risk reduction strategies. Journal of Business Venturing 15: $393-410$.

Simons T, Roberts PW. 2008. Local and non-local pre-founding experience and new organizational form penetration: the case of the israeli wine industry. Administrative Science Quarterly 53(2): 235-265.

Stock JH, Wright JH, Yogo M. 2002. A survey of weak instruments and weak identification in generalized method of moments. Journal of Business and Economic Statistics 20(4): 518-529.

Tripsas M, Gavetti G. 2000. Capabilities, cognition, and inertia: evidence from digital imaging. Strategic Management Journal 21(10-11): 1147-1161.

Ucbasaran D, Lockett A, Wright M, Westhead P. 2003. Entrepreneurial founder teams: factors associated with member entry and exit. Entrepreneurship: Theory and Practice 28(2): 107-128.

Walsh JP. 1995. Managerial and organizational cognition: notes from a trip down memory lane. Organization Science 6(3): 280-321.

Wezel FC, Cattani G, Pennings JM. 2006. Competitive implications of interfirm mobility. Organization Science 17(6): 691-709.

Whalen G. 2002. Charter flips by national banks. Working Paper 2002-1. Office of the Comptroller of the Currency. Washington, D.C.

Wooldridge JM. 2002. Econometric Analysis of Cross Section and Panel Data. MIT Press: Boston, MA.

Wu B, Knott AM. 2006. Entrepreneurial risk and market entry. Management Science 52(9): 1315-1330.

\section{SUPPORTING INFORMATION}

\section{Additional supporting information may be found in the online version of this article:}

Table S1. Instrumenting all interaction terms with $\mathrm{IV}(\mathrm{s}) \times$ moderator(s) as new IVs

Table S2. Instrument all interaction terms with additional IVs, but use LIML estimates

Table S3. First stage regressions 